\title{
Students Support Services at a Scientific University
}

\author{
Claude DECORET \\ Laurent DE BERTI
}

University CLAUDE BERNARD LYON1, Bât. 305

43 Bd du 11 Novembre 1918

69622 VILLEURBANNE CEDEX

tel : $(+33) 72448279 \quad$ fax : $(+33) 72431160$

email : decoret@chitheo1.univ-lyon1.fr, deberti@chitheol.univ-lyon1.fr

\begin{abstract}
In this paper, we intend to describe the functioning of the services for handicapped students at our university. Details of functioning are given which show The co-ordination role of the Handicap Mission between teachers, students and administration. Links between the Handicap Mission and research and development laboratories teams, librarians, etc. are essential for diminishing handicap and facilitating studies in the framework of integration. This last point has specific aspects in a scientific university.
\end{abstract}

\section{Introduction}

The access of study for handicapped persons at the university level is theoretically facilitated with the extensive use of microcomputers and related technologies such as adaptive technologies[1]. More and more materials are on electronic format and those materials seem to be more and more accessible by handicapped persons. The second trend is not obviously irreversible, as for instance the tendency for Graphical User Interface G.U.I. [2] , source of difficulties for blind and Visually impaired people. Due to these trends or/and general evolution of our developed societies, the number of handicapped students is growing slowly and most universities have created services for facilitating a two-directions communication [3] (teacher-student, student-teacher) on the basis of technological availability and in many cases helping to solve problems of mutual comprehensivness. Does it means for the long term a full insertion of persons with differences or their exclusion from the main stream? Nobody can pretend have the answer, which nevertheless is "capital" for our society [4] and we have to be aware of the dangers of uniformity [5]

\section{General situation}

\subsection{In the world and especially UNITED STATES}

Students support services are of different kinds depending generally from the historical origin. For instance, at Baruch College [6] CUNY (City University of New York) already in 1977 , existed a service devoted essentially to computer science and 
aptative technology. This service was shared by the 17 colleges of the CUNY. Visually impaired students could come in a room with many computers equipped with Braille terminal or voice synthetizer. Since lots of university have created disabled student support services more or less successfully in regards with the number of disabled students which is $2.83 \%$ in California [7]. Associations such as AHEAD aim to develop experiment exchange, to help them some books were published [8,9]. In England, where the central organisation, Royal National Institute for the Blind (R.N.I.B.), is very developed, a central service exists [10] and has a booklet, in various format, designed to inform students, giving them counselling for their attitudes, right and difficulties to overcome, and it is logical that each university more or less refer to this central English service. In USSR, in 1983, existed also on a central basis, a service of this kind to help disabled students, and referring here to visually impaired, as an example, blind students in mathematics or computer science could find somebody to read specialized papers (program listing, e.g.). At the same period, in France, due to individual needs or initiatives, some experimental services were created as in the university Paris VI and in the university Paris VII, known as the "Relais Handicap" or an inter-university service in Lyon the FIDEV (Formation Informatique pour DEficient Visuel) .

Since, more and more handicapped students pursue studies at university level in many countries, and in parallel, many services have been created and developed. So that it is difficult to have an overview $[8,9]$.

\subsection{In FRANCE}

In France, for example, each university (about 90 ) have at least a representative in charge of supporting handicapped students and the ministry have a special services to co-ordinate their actions. In our area, the Rhone-Alps region, three locations have developed services, each one with a special feature, university of Savoy (Chamberry) with more experiment in the field of problem of hearing, universities of Grenoble in the field of motor impaired students and universities of Lyon in the field of blind and Visually impaired student. Mutual exchange of experiments is constant to avoid specialisation and concentration of students with the same impairment in the same universities. The three universities of Lyon (LYON III, juridical and language studies, LYON II, human science studies and LYON I, science and medical studies) develop services and moreover a common resource centre exist for producing material for blind and Visually impaired students and teachers. Our concern in this paper is with the university LYON I and specific questions of scientific studies for handicapped people.

\section{Local situation}

What people are registered as handicapped students in our university UCBL (University CLAUDE BERNARD LYON1) ? At this point, we have to make the difference between handicapped and impaired people, for if all buildings would be accessible by wheelchairs[11], there would be no handicap for people obliged by their impairment to move in wheelchairs. But if impairment is not retained as the unique criterium, we have to appreciate the difficulties of each person entering the university to pursue studies when these difficulties are due to some inadequacy between what they have to do and what they are able to do without various support to be furnish by the 
university. It is to be said that mental diseases are not taken into account. So, facing such questions, what services are qualified to perform that appreciation? The response is made through a synergy between medical service for students, the handicap commission, the mission and concerned teachers. We will define the role of each one in what follows. First is to be mentioned that the work is facilitate by a recent legal "circular" from the ministry date: march 1994) which gives the legal procedure to for asking as handicapped students and define the disposition to be taken for passing exams.

\subsection{Prevent medical service for students.}

This service, which is inter-university in our town, is the only one qualified to give the right for a student to pass exams with the special dispositions displayed in the ministry "circular". These dispositions consist of giving the third-time (the right to have a third-time more than the duration time for other students and prescribing means to diminishing handicap (the right to use adaptive devices, to be helped by qualified persons, to pass exams in a separate room, etc. depending the case of handicap.

\subsection{The Handicap Mission (M.H.).}

This service consists of Claude DECORET, a secretary also blind and a CES, that is a sighted people half-time without special qualification and two computer science engineers in charge of adapting technologies for the special needs of handicapped students in a scientific and medical university. One (Laurent DEBERTI) is full-time as making his military service and the other fifth-time employed by the CNRS. The M.H. is qualified to manage the money allocated by the university or by the minatory (special disposition for deaf students) and needed for passing exams and for following studies all along the year. At this point, students supported by the service are not only the ones being the benefit of the third-time for exams. We will describe below more precisely the various ways of working of the mission. The M.H. by various means and in close collaboration with the commission handicap works to make known by students its existence and the services available.

\subsection{The handicap commission.}

It is composed of all handicapped students by definition. There are about 40 handicapped students on 24000 students.

\section{Supports available}

\subsection{On the campus}

4.1.1 The M.H. The role of this Mission is to co-ordinate actions, supports and information, promote research. The office of the M.H. is located near the main entrance of the campus. There, students finds documentation on their rights, procedure for third-time right, etc. They may have advises and inquiries concerning accessibility of studies, summer stages, after studies employment opportunities, etc. 
4.1.2 The university library. It manages in closed collaboration with the M.H. a room equipped with various devices, accessible at opening hours for handicapped customers. Moreover, a person is present two hours a day to help eventually students in the uses of devices. The equipment is Visually impaired and blind oriented facilities and consists of what it could be expected, that is, computer, with voice synthesiser (French and English) Apollo, a Braille printer INDEX, a screen reader, an ordinary printer, an electronic magnifier, a scanner READING EDGE.

There also, students have the opportunity to connect to the network and enter the world of INTERNET. They have some hours of teaching and then they receive an electronic address. The M.H. have created its own WWW public server (http://www.univ-lyonl.fr/fb/ch/ch.html)

4.1.3 towards teachers. At the beginning of the university year, teachers concerned by having an handicapped student is usually taught by this student how to manage with him. As soon as possible at the beginning of the year, the M.H. recommends students to take contact with their teachers. Then, teachers find complementary inquiries at the M.H. and plan with it the support to be done, as pedagogical sustainments, if needed, assistance for passing exams, note takers for deaf.

4.1.4 administration services. The M.H. is a kind of administrative service closely related with other services. It is directly depending of the university president. The M.H. does not replace other services which act regularly towards handicapped students as regular students. Special disposition concern the registration form, on which students can specify if they are asking for a third-time to pass exams

\section{2 resource centre}

This centre was created several years ago especially for blind and Visually impaired students and is shared by the three universities of Lyon. An agreement between this centre (FIDEV) and the university LYON1 that the FIDEV provides Braille formatted text of Exams and transcribes Braille copies from students to normal print. The FIDEV has also a MINALTA for making raised drawings which at the disposal of students and teachers on their site. These two points (Braille and raised draws) are very important for scientific studies because it needs very skilled people (Braille mathematics at high level) and knowledge of what is to transform or not to obtain a raised draw from a printed paper.

\section{Commission handicap.}

At the beginning of the university year, the M.H. organises a meeting of handicapped students, known as such from preceding years or asking for third-time. At this meeting, students are informed on the procedure to be followed for obtaining third-time. There, they can make acquaintance and exchange experiences, discuss problems, and they are informed of the various means offered by the university and they can ask for new means to be found for their own needs. A reduced commission is formed ( 6 to 8 people) to follow current affairs with the M.H. The reduced commission meet about each 3 weeks and the large commission three times a year. Very often, a new 
students is a new experiment for him, for teachers and for the M.H. because our university offers a large range of studies in physics, chemistry, biology, medicine, pharmacy, mathematics, computer science, etc. We take care, as much as possible, of classroom day-life, to find or suggest solutions when questions arrived, practical and sometimes psychological. For instance, chemical studies for blind are not withdrawn, because examples are known of blind professionally active in chemistry as theoreticians or documentalists. Motivated students are generally successful in their study and it is often the case because they are looking themselves as pioneering in their field. They are spontaneously ready to promote scientific studies among handicapped scholars and so, participate to various meetings in schools or are present to give inquiries at the time when scholars comes to university to know what the university offers as study (one special day is reserved for such a visit, each year). They are also present when students come to take inscription at the university at the end of the year.

\section{6. results and future}

As it can be seen in this paper, most aspects of insertion of handicapped students are very similar at whatever university [12]. Nevertheless, some aspects are specific to scientific studies such as physic, chemistry, biology, etc. relative to human science, juridical, language, etc. studies. To my point of view, the differences are essentially related to the question of specific writing and speaking of formulas[13], drawings, etc. and the questions of technical practices, such as in chemistry for instance. These questions are particularly sensitive in the case of blind and Visually impaired students So, in what follows, I will emphasises examples in this field.

First of all, the aim of university studies is not only to obtain diplomas but above all to find a job[14]. The consultative role of the M.H. with its background experience is primordial as well as for students as for teachers. It must take into account professions or jobs already known as available for disabled people, it must also take into account the growing and to be enhanced facilities for new professions and jobs due to technical progress and due to diversification, evolution and changes of working places. So a reasonable part of new experiment is to be kept in mind when counselling a student or a teacher group. It usually concerns the degree of adaptations needed to obtain the required knowledge level. For instance, what is the degree of practical knowledge to require for a blind student in chemistry, concerning practical experiments with manipulations of chemical products, when the purpose of such studies is to find jobs in documentation or theoretical work on computer or even teaching jobs. It is a hard question for teachers who have eventually to deliver the same diploma as for other and who have to adapt experiment when possible or to control the level of knowledge acquisition when the handicapped student works as specific help in a team (most often for practical experiments students work by two or three, due in general to the lack of available places).. These questions are very general, answers are very diversified depending on many factors, because the degree and type of handicap vary for almost each disabled student, the degree of imagination of teacher, and his/her good will, the availability of adaptive means at the university (such adaptation are often very expensive). It must be said that the good will is the most efficient way to overcome difficulties and are compensate by a rigorous control of acquisition of knowledge. In not 
rare cases, teachers let me know that they are impressed by the simplicities of adaptation needed, students are no so handicapped as we thought before knowing them and furthermore they may have a dynamic role for other students in the same classroom, perhaps due to their need of help and consequently facilities of communications. [15]

\section{Concerning to blind people, question of transcription}

As many universities, transcriptions are made by hand in most cases. A paper copy for exams are given to the resource centre (FIDEV). At this centre, people, there are people knowing perfectly well Braille mathematical signs (French code), there are blind people among them. They can do the work of transcription and reversibly when Braille copies are given to them. The main problem is to obtain paper copy in time, teacher are sometimes reluctant to give their exams subject (or to prepare) too long before. As it is explained before, it is possible to perform raised drawings, electronic schemes, etc. often with adaptation of the drawings to take into account that the touch with fingers is sometimes very different from the view in affording and transmitting information. Such changes are often made in agreement with the concerned teacher ( what to suppress, transform or emphasised, or enlarge).

Concerning special signs, as mathematical ones, we are aware that number of teachers write their exams and courses on computers [16]. They use word processor facilities for such signs and a growing number write in an special language named TeX, especially in mathematical and physic departments of the university. Here, the question of automatic transcribing occurred and a research and development little programme is developing to transform TeX into mathematical Braille. Similar work seems to have been done for transferring TeX towards files readable by synthesised voices. The M.H. pilots this programme.

\section{Reference}

1. ORIOL-PARIS Nathalie, These de doctorat d'economie, Univ LOUIS LUMIERE LYON II, 29 juin 1993, Insertion professionnelle des aveugles: du marche du travail au processus de production.

2. Project Archimede C.S.L.I. (Centre for the Study of Language and Information) Standford University

3. "Journée Nationale de sensibilation et d'échanges sur l'accueil des étudiants handicapés à l'Université."

Claude Bernard Lyon I University - January 18, 1990

4. Albert Jacquart, Eloge de la difference ...

5. Peter Muhlhauser : Sauver Babel (sauvguard Babel), courrier de l'U'NESCO, French braille editon, no64 marh 1994 p68

6. Baruch College

17th Lexington ave

1010 New York NY 
7. Jeffrey C. Senge : Print accessibility for print disabled students in postsecondary education CSUN 1994

8. Karin J. Spencer : From access to equity, ressource manual for service providers

AHEAD, Colombus Ohio.

9. Directory of college facilities and services for people with disabilities Thomas and Thomas ORYX Press

3rd edition 1991

10. RNIB at Peter Borogh College

11. "Journée nationale de sensibilisation et d'echanges sur l'accueil des étudiants handicapes à l'Université" Claude Bernard Lyon I University - January 18,1990 p. 63

12. READAPTATION, $\mathrm{n}^{\circ} 407$ Febbruary 1994 "Les Etudiants handicapés" published by ONISEP 168, bd Montparnasse 75014 Paris (France)

13. T.V. RAMAN, "Audio System for Technical Reading" presented to the faculty of the graduate School of omell University in partial Fullfilment of the Requirements for the degree of Doctor of Philosophy ; May 1994

14. ZAID L. VOGEL J. "Insertion professionnelle des personnes handicapées en France",

Informations techniques $\mathrm{n}^{\circ} 4$ (C.R.E.A.I.), Nantes, Octobre 1985. 10p.

15. HERNANDEZ C. "Handicaps handicaper ?", Edition sociale (compte-rendu du Colloque nationale : handicaps, société, libertés, le droit de vivre différent, libre te heureux), 1978. pp. 9-28

16. This book, Seminar on Access to Electronic Information for Visually Impaired Persons. part 3.1 